\title{
ADAPTIVE REUSE OF HISTORICAL HERITAGE SITES: CONTEXTUAL FRAMEWORKS, 'RESTRICTIVE' OR 'CHALLENGING' FOR THE REDESIGN?
}

\author{
MICHELLE BYLEMANS \& NATHALIE VALLET \\ Faculty of Design Sciences, University of Antwerp, Belgium
}

\begin{abstract}
Different contextual frameworks seem to work as 'restrictive' for redesign during the adaptive reuse of all kinds of historical heritage sites, all over the world, that have lost their initial function. However, different contextual frameworks can also work as 'challenging' for the redesign, as we found out during the adaptive reuse of particular historical heritage sites, being the former Agriculture Pauper Colonies of the Flemish municipalities 'Wortel' and 'Merkspas' (i.e. in the Province of Antwerp, Belgium), into an Inclusive Economic Participation (IEP) Site. This concept of an 'IEP Site' was considered to be an interesting option for reuse by the local governments involved. After all, the main objective of an IEP Site relates strongly to the initial function of both colonies (i.e. the support of poor citizens). In this paper, we will demonstrate that the 'heritage framework', 'institutional framework' and 'strategic ambition framework' of the reuse not only works as 'restrictive', but also works as 'challenging' and 'inspiring'. As such, the redesign, involving the architectural techniques of 'photoshops', 'scenarios' and 'organograms', resulted in creative, flexible, innovative and mind-opening solutions for all partners involved.

Keywords: historical heritage sites, adaptive reuse, contextual frameworks, restrictions, challenges, redesign, creative, flexible, innovative, mind-opening.
\end{abstract}

\section{INTRODUCTION}

This paper is based on the results of a research project on the redevelopment of the two former Agriculture Pauper Colonies of the two Flemish municipalities 'Wortel' and 'Merkspas' (i.e. in the Province of Antwerp, Belgium). Because of compartmental landscapes, consisting of a grid pattern of tree alleys, ditch structures and rectangular plots of meadows, woodland and farmland, as well as distinctive buildings, that are original and still (largely) preserved from their creation to this very day, both Colonies are considered as 'historical heritage sites'. Because of their value, both Colonies are already protected as 'cultural heritage landscapes' since 1999 (De Borgher [1]; De Sadeleer and Plomteux [2]). In addition, both Colonies are also trying to gain the recognition of 'UNESCO World Heritage' by 2018, together with the other five Colonies in the Netherlands, that were established in the same period and developed with the same quality (UNESCO [3]).

In view of this redevelopment, it is considered important, not only to respect and retain this historical value, but also to add a contemporary layer that provides value for the future. This kind of redevelopment is called 'adaptive reuse' (Latham [4]; Wilkinson et al. [5]; Bullen and Love [6]-[8]; Plevoets and Van Cleempoel [9]). Our research team at the Faculty of Design Sciences (i.e. at the University of Antwerp, Belgium), worked out a design project on the adaptive reuse of both Colonies into an Inclusive Economic Participation (IEP) Site, that respects the initial function, retains the historical heritage and adds a new perspective on both Colonies (i.e. the three terms of adaptive reuse). During the process of adaptive reuse, different contextual frameworks, linked to these particular historical heritage sites, need to be taken into account. This brings us to the central problem statement of this paper: 'How can we deal with different contextual frameworks during the process of adaptive reuse? And 
in particular, how can these contextual frameworks not only work 'restrictive', but also work 'challenging' for the redesign?'

As far as the structure of this paper is concerned, this small introduction is followed by three larger paragraphs. In the first paragraph, we clarify the original destination and identity of both Colonies, by means of their evolution, in order to trace what has made them become 'historical heritage sites'. In the second paragraph, we clarify the completely new concept of an 'Inclusive Economic Participation (IEP) Site' as the future destination of both colonies. And in the third paragraph, we distinguish three contextual frameworks that need to be taken into account during the process of adaptive reuse, being: the 'heritage framework', 'institutional framework' and 'strategic ambition framework'. Finally, we end this paper by a conclusion or an answer to the research questions of this paper.

\section{ORIGINAL DESTINATION AND IDENTITY}

In 1822, respectively 1825, the Agriculture Pauper Colonies of the Flemish municipalities 'Wortel' and 'Merksplas' (i.e. in the Province of Antwerp, Belgium) were developed, together with the five Agriculture Pauper Colonies in the Netherlands. In 1818, the Dutchman Johannes van den Bosch provided their construction as a 'solution' to the extreme poverty around that time, after many years of prosperity, in the low Countries (i.e. the Netherlands, Belgium and Luxembourg) (De Borgher [1]; De Sadeleer and Plomteux [2]). The benefits of this 'system' were twofold. On the one hand, poor people (e.g. beggars, vagrants, orphans, disabled, diseased, elderly, etc.) were housed and provided with care, education and employment, in order to help them escape from poverty in a more structural way. On the other hand, poor people cultivated large amounts of meadows, woodland and farmland, which decreased the need of paid workers.

First of all, large areas of uncultivated heathland in the two Flemish municipalities 'Wortel' and 'Merksplas' were purchased, in order to install the Agriculture Pauper Colonies. A plan with a clear and clean design was drawn up for both areas, with a surface of 552 ha respectively 480 ha, dividing these areas into compartmental landscapes, with a grid pattern of tree alleys, ditch structures and rectangular plots of meadows, woodland and farmland, and distinctive buildings, such as houses, schools, workplaces, farms, pharmacies, chapels and cemeteries (De Borgher [1]; De Sadeleer and Plomteux [2]).

Over the years, the landscapes were further developed, while the buildings were renovated and expanded, however in some cases unfortunately also demolished. The first renovations of existing buildings started in 1870, but also in the next years, renovations were carried out. The period between 1880 and 1890 was one of many new buildings, which form the majority of the buildings that are still present today. Because of the evolution for some of the buildings towards a penitentiary around 1950, once again new buildings had to be built. Of course, these $20^{\text {th }}$ century buildings with a prison function, have a less valuable historical quality than the $19^{\text {th }}$ century buildings. Because of a fire or a loss of function in combination with a limited valuable historical quality, some buildings were unfortunately also demolished over the years (De Borgher [1]; De Sadeleer and Plomteux [2]).

Since the abolition of the 'Law on Vagrancy' in 1993, the Agriculture Pauper Colonies of the two Flemish municipalities 'Wortel' and 'Merksplas' have lost their initial function and most of their buildings are faced with vacancy (De Borgher [1]; De Sadeleer and Plomteux [2]). As a result, the future of both Colonies has become very uncertain. A discussion among policy makers is brought up on what their future should entail. For some, both Colonies should get a new destination with a focus on tourism (i.e. the local governments ambition), while others stay foot to the initial function of supporting poor citizens, because of this still existing problem in our society (i.e. the provincial government ambition). 


\section{FUTURE DESTINATION: AN IEP SITE?}

The suggestion of an Inclusive Economic Participation (IEP) Site as future destination of both Colonies, unites these different ambitions of policy makers. This means, both Colonies will not only get a new destination with a focus on tourism (i.e. local governments ambition), but also maintain their initial function of supporting poor citizens (i.e. provincial government ambition), yet in a more contemporary way. Compared to the past, both Colonies will not remain exclusive sites for poor citizens, or as we broadened this group as 'socially deprived or vulnerable citizens', but will however become inclusive sites for all citizens. As a result, socially deprived or vulnerable citizens are more integrated in our society and are more likely to break their vicious cycle of poverty. In other words, this totally new concept of an IEP Site is another, better and more contemporary way or 'solution' in order to address all problems associated with poverty as we know it today (i.e. not being able to participate in our society), and as a result a perfect option as future destination of both Colonies.

This totally new concept of an IEP Site is launched and elaborated by our research team at the faculty of Design Sciences (i.e. at the University of Antwerp, Belgium), consisting of researchers within disciplines of social sciences (i.e. (social) economy and management) and design sciences (i.e. (interior and landscape) architecture, urbanism and spatial planning). We defined an IEP Site as 'a location, that connects different kind of public, (social) profit and/or private organizations, that support the (social) economic participation into our society, of all citizen, but in particular the growing amount of socially deprived or vulnerable citizens, both as a consumer of goods and/or services, and as a producer of labor (Termote [10]; Vranken [11]; Coene et al. [12]; Termote and Galand [13]; De Nys-Ketels et al. [14]; Vallet et al. [15]-[18]). Let us take this definition apart, in order to explain the different features of an IEP Site (Vallet et al. [17], [18]).

First, this definition reveals something about the location of an IEP Site. It is important that an IEP Site connects different organizations. These organizations can be accommodated (1) within one single building (i.e. the single-building IEP Site), (2) within a restricted area (i.e. the campus IEP Site), (3) within a certain neighborhood (i.e. the neighborhood IEP Site) or (4) by means of a digital 'track' of settlements throughout an entire city (i.e. the Satellite IEP Site). In this research project, the application is an example of the campus IEP Site (Vallet et al. [17], [18]). Because of both the individual operation and spatial dispersion of the large amount of already existing organizations, such a 'connection' seems to be necessary. These two different 'defects' generate physical and mental 'barriers' to actually benefit from these initiatives (Lucas [19]; Opdebeeck et al. [20]; Laenen [21]; Sannen [22], [23]; Steenssens et al. [24]; De Corte and Kolijn [25]).

Secondly, this definition reveals something about the activities, that can be provided on an IEP Site. In particular, an IEP Site wants to provide socio-economic activities or activities that improve the (social) economic participation into our society. However, an inclusive mix need to be created or a mix of socio-economic activities and other activities with a focus on tourism, care, education, agriculture, etc., in order to make this IEP Site open for everyone (Vallet et al. [17], [18]).

Thirdly, this definition reveals something about the citizens, that can either make use of (i.e. the side of the consumer), or be employed in (i.e. the side of the producer) these activities. In particular, an IEP Site wants to offer activities for socially deprived or vulnerable citizens. However, a social mix need to be created or a mix of socially deprived or vulnerable citizens and other citizens, in order to make this IEP site open for everyone. Even within the group of socially deprived or vulnerable citizens, no group may dominate the rest of the group (Vallet et al. [17], [18]). 


\section{CONTEXTUAL FRAMEWORKS}

During the transition from the original destination and identity of both Colonies (i.e. paragraph 2) to an IEP Site as the future destination of both Colonies (i.e. paragraph 3), different contextual frameworks were brought to light. These contextual frameworks, that need to be taken into account, make the preservation, the restoration and the maintenance of these historical heritage sites and their historical heritage buildings, not only more difficult for the designer, but also less attractive for developers.

In view of this transition, the buildings should not only be reused, but also be adapted for this reuse. This kind of process is called 'adaptive reuse' (Latham [4]; Wilkinson et al. [5]; Bullen and Love [6]-[8]; Plevoets and Van Cleempoel [9]). Adaptive reuse of a building can be seen as 'a process that not only makes a change in function of a building (i.e. a purpose other than which a building was designed for), but also applies other alterations (i.e. architectural interventions) to this building, in order to embrace this new function' (Bullen and Love [6]-[8]; Plevoets and Van Cleempoel [9]). In other words, adaptive reuse involves converting a building to undertake a change of use (Latham [4]; Wilkinson et al. [5]; Bullen and Love [6]-[8]; Plevoets and Van Cleempoel [9]).

This leads us once again to the central problem statement of this paper: 'How can we deal with different contextual frameworks during the process of adaptive reuse? And in particular, how can these contextual frameworks not only work 'restrictive', but also work 'challenging' for the redesign?'

During the process of adaptive reuse of some buildings selected for the reconversion of both Colonies into an IEP Site, we faced three types of contextual frameworks, being: the 'heritage framework', 'institutional framework' and 'strategic ambition framework'. First, we explain in which way these frameworks make the process of adaptive reuse more difficult for the designer. Secondly, we explain how this at first sight seem to work 'restrictive'. And thirdly, we 'prove' that this can also work 'challenging' for the redesign.

\subsection{Heritage framework}

The first contextual framework that we defined, is the 'heritage framework'. This framework makes the process of adaptive reuse more difficult for the designer, because of the guidelines, codes and regulations, attached to historical heritage buildings. After all, these guidelines, codes and regulations give more information about different aspects, that need to be respected during the process of adaptive reuse. In most cases, they impose limitations, that may obstruct the application of new materials or techniques, required for adaptive reuse, and as a result, they may restrict the new function (Bullen and Love [6]). In other words, this framework ensures, that adaptive reuse won't affect the heritage value of historical heritage buildings, that at any rate need to be preserved for the future generation (Latham [4]). After all, it is important, that historical heritage sites will be preserved, repaired and maintained in the best way possible.

More specifically, during the process of adaptive reuse of both Colonies into an IEP Site, for example the following rules had to be respected: 'as much historical heritage components as possible, must be preserved' and 'no architectural interventions may be applied to historical heritage buildings, unless they are necessary for a recovery in their original state'. At first sight, both rules lead to restrictions, being a restriction in the kind of function that can be assigned to historical heritage buildings (i.e. the 'consequence' of the first rule), and a restriction in the quality improvement of historical heritage buildings, in order to embrace this new function (i.e. the 'consequence' of the second rule). However, both rules can also be 'challenging' for the redesign. 
Let us take the former 'Potato Barn' at the Colony of 'Merksplas' as an example, in order to explain how this framework, or these two rules, can not only work 'restrictive', but also work 'challenging' for the redesign. This particular building stands out for a sloping floor on both ground level and second level, as well as very dark interiors, because of a sunken floor in combination with small windows.

According to the first rule, the sloping floor must be preserved. As a challenge, we needed to search for functions that can make optimal use of this sloping floor. By realizing a wellness on the ground floor, with water basins placed on top of this sloping floor, you can get inside these basins, in shallow water, and swim to the other side of these basins, into deeper water. In addition, by realizing a cinema on the second floor, with a small grandstand placed on top of this sloping floor, you can see the screen in front of you, from any sitting position. Nevertheless, from the start, some partners involved were not in favor of this sloping floor and wanted to remove it, instead of preserving it. In order to convince all partners involved of the added value of this sloping floor, we used the visualization technique of 'scenarios' (Bylemans et al. [26]). In Fig. 1, two different 'scenarios' of the former 'Potato Barn' at the Colony of 'Merksplas' are given, of which one without its sloping floor (i.e. in this case the sloping floor is removed) (see above), and one with its sloping floor and its appropriate functions (i.e. in this case the sloping floor is preserved) (see below). We used the contrast between these different 'scenarios' as an eye-opener, to distinguish the better of the worse. As such, we have dealt with this rule in a creative way, or in other words, we have dealt with this first framework by means of a creative solution for the redesign.

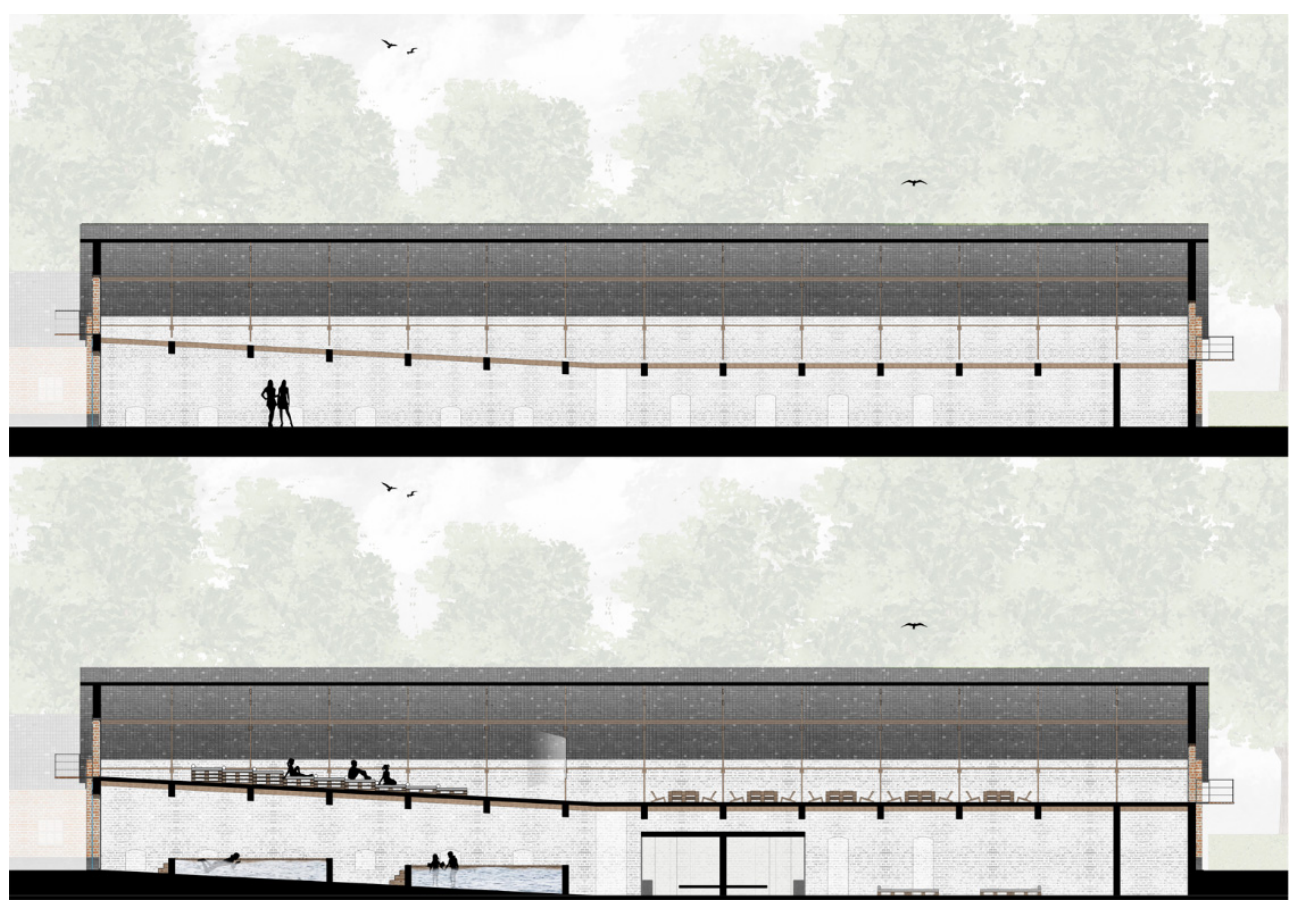

Figure 1: Two different scenarios of the former 'Potato Barn' at the Colony of 'Merksplas': one without its sloping floor (see above) and one with its sloping floor in combination with its appropriate functions (see below). 
According to the second rule, no additional openings may be applied, in order to bring more light into this building. As a challenge, we needed to prove to all partners involved, that these additional openings, on the one hand are rather small architectural interventions, that are not visible from the outside, and on the other hand deliver several benefits. By lowering the windows in the back and by removing a part of the floor together with a part of the roof, as first and most important benefit, more light is brought into the building. As second benefit, the effect of a Greek or Roman 'Compluvium' (i.e. an opening) above an 'Impluvium' (i.e. a sunken water basin) is obtained, because of natural light, that reflects directly on the water of a sunken water basin, that is placed bellow the opening in the roof. As additional benefits, the beams in the ceiling are exposed and the interiors of the building are experienced bigger. In order to convince all partners involved of the added value of additional openings, we used the visualization technique of 'scenarios' (Bylemans et al. [26]). In Fig. 2, two different 'scenarios' of a wellness, as an appropriate function for this building, are given, of which one without additional openings (see on the left), and one with additional openings (see on the right). We used the contrast between these different 'scenarios' as an eye-opener, to distinguish the better of the worse. As such, we have dealt with this rule in a flexible way, or in other words, we have dealt with this first framework by means of a flexible solution for the redesign.

\subsection{Institutional framework}

The second contextual framework that we defined, is the 'institutional framework', which makes the process of adaptive reuse more difficult for the designer, because of the decisions that already have been made in existing spatial plans (i.e. in this case an implementation plan for both 'Wortel' and 'Merksplas', as well as a master plan for only 'Merksplas'), studies and other policy documents. After all, these decisions are (nearly) binding and leave little or no freedom for the designer.

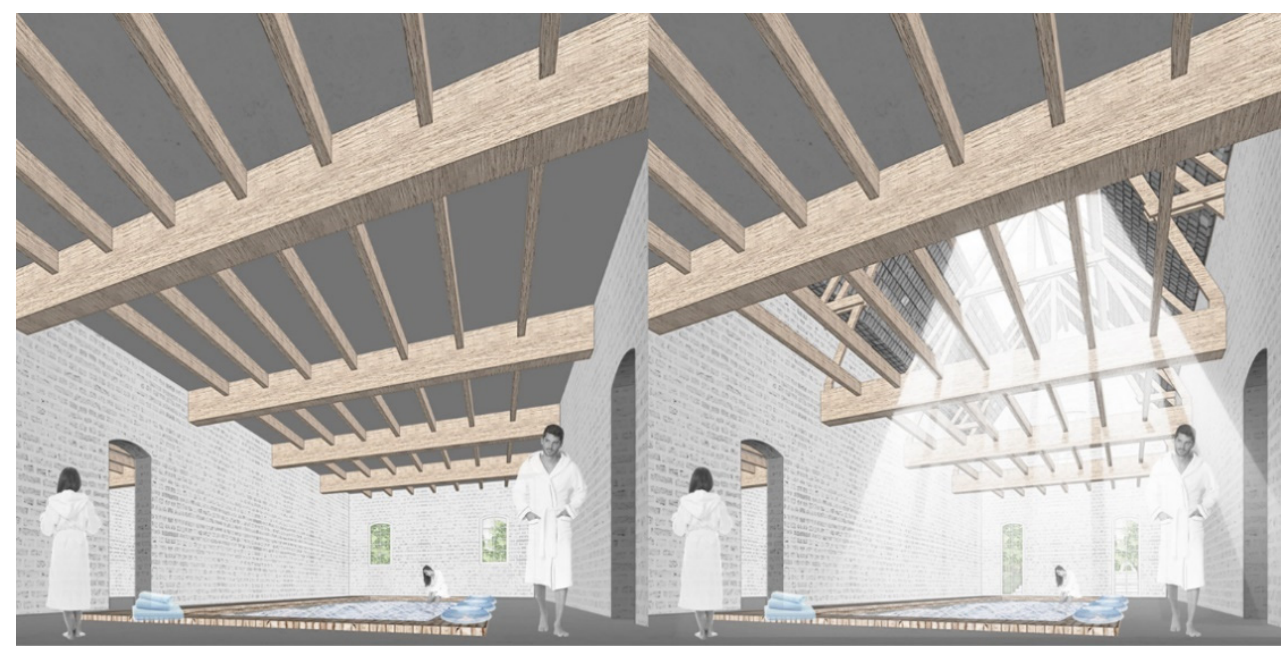

Figure 2: Two different scenarios of a wellness, as an appropriate function for the former 'Potato Barn' at the Colony of 'Merksplas': one without additional opening (see on the left) and one with additional opening (see on the right). 
More specifically, during the process of adaptive reuse of both Colonies into an IEP Site, there were a lot of buildings, that already have been given a new destination. At first sight, this seems to work 'restrictive', as no other destinations for these buildings can be examined, and as a result, less buildings are available for the other destinations. However, this can also work 'challenging' for the redesign.

Let us take the existing 'Prisoners Museum' at the Colony of 'Merksplas' as an example, in order to explain this challenge. This museum wants to move to another and better location. However, none of the still vacant buildings meets the requested surface. In addition to one of the still vacant buildings, we launched and elaborated the idea of so-called 'museum boxes', in order to meet the requested surface for this museum. Museum boxes are placed outside these buildings and distributed in open space, in order to win more space. In order to convince all partners involved of the added value of museum boxes placed at both Colonies, we used the visualization technique of 'photoshops'. 'Photoshops' are photos, in which an item (i.e. in this case a museum box) has been photoshopped, in order to show this item 'fits' the reality (Bylemans et al. [26]). In Fig. 3, one particular 'photoshop' is given, showing a museum box placed at one particular location at the Colony of 'Merksplas'. This box consists of a steel frame, that can be filled in with transparent or dense materials, and can be extended in function of a bicycle rack (see on the left), as well as a bench (see on the right). In addition, one side of this box displays a text, that gives more information about the content of this box. In conclusion, we have dealt with this second and 'institutional framework' by means of an innovative solution for the redesign.

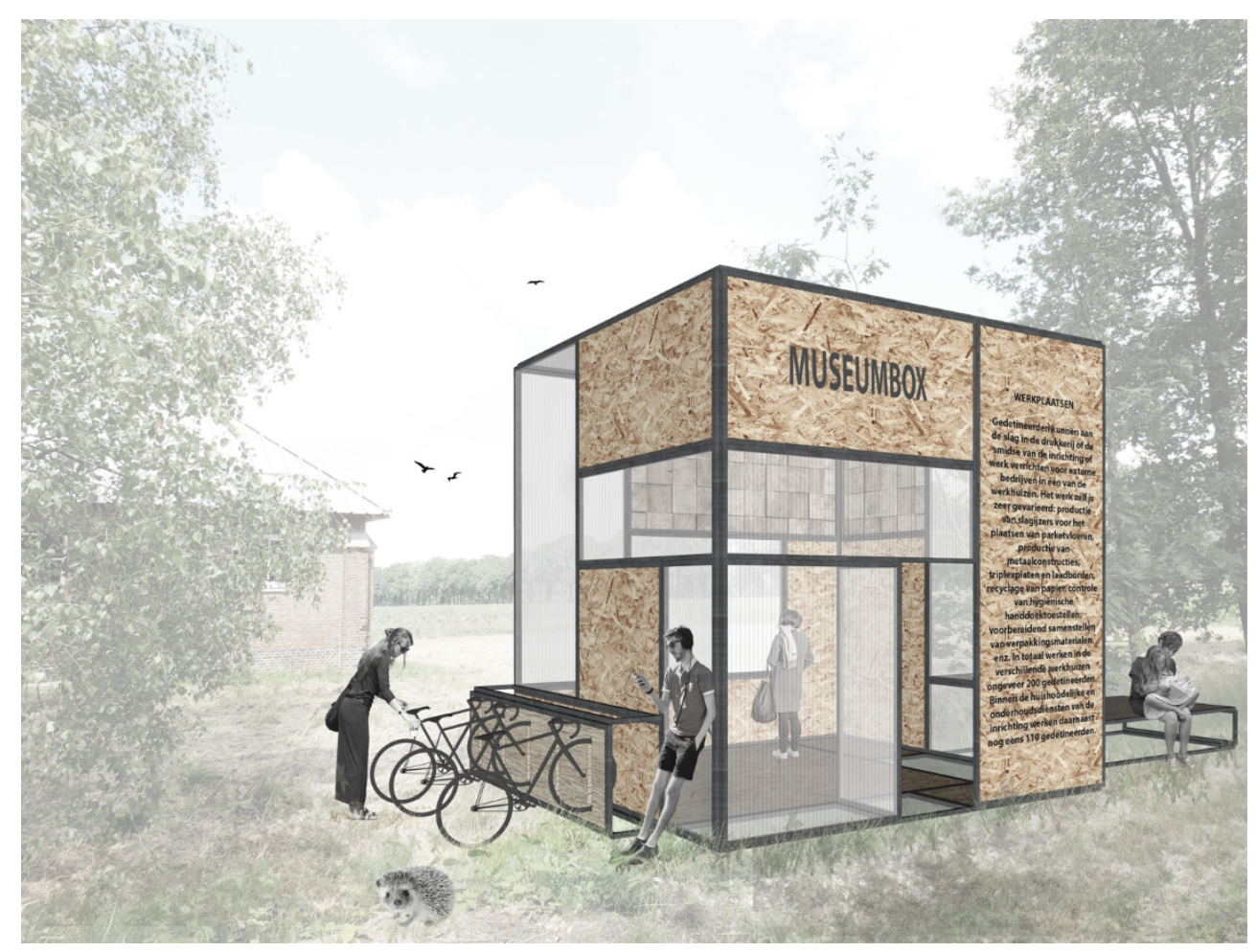

Figure 3: One particular photoshop showing a museum box placed at one particular location at the Colony of 'Merksplas'. 


\subsection{Strategic ambition framework}

The third contextual framework that we defined, is the 'strategic ambition framework', which makes the process of adaptive reuse more difficult for the designer, because of the different and in some cases even conflicting opinions of all partners involved (i.e. policy makers of the local governments and provincial government, members of public, (social) profit and private organizations, and (interior and landscape) architects, urbanists and spatial planners). After all, the process of decision making becomes more complex, seeing the large amount of all partners involved, with different experiences, beliefs, interests and values for each of them (Bullen and Love [6]).

More specifically, during the process of adaptive reuse of both Colonies into an IEP Site, there was a lack of clarity, about on the one hand what kind of activities should be provided (i.e. tourism activities or other activities with a focus on care, education, agriculture, etc.), and on the other hand what kind of citizens (i.e. tourism citizens or socially deprived or vulnerable citizens) should either make use of, or be employed in, different kind of activities.

At first sight, this seems to work 'restrictive', as a black-and-white choice must be made between the one or the other. However, this can also work 'challenging' for the redesign.

In the design process, this black-and-white choice can be avoided. First, different activities can be combined, and as a result, a so-called 'inclusive mix' can be obtained at both Colonies. Secondly, and in like manner, different citizens can be combined, and as a result, a so-called 'social mix' can be obtained at both Colonies. In order to convince all partners involved of the added value of the reconciliation of different activities and different citizens in one and the same design project, being the adaptive reuse of both Colonies into an IEP Site, we used the visualization technique of 'organograms' (Bylemans et al. [26]). In Fig. 4 (see the previous page), one particular organogram is given. First, this organogram shows possible synergies or links between tourism activities and other activities with a focus on care, education and agriculture (see dotted lines). Secondly, in addition, this organigram marks all activities that can be used as so-called 'socio-economic activities' or those activities that are available for all citizens, but in particular socially deprived or vulnerable citizens (see hatched surfaces). The suggested 'day care' represents for instance a synergy between 'care' and 'tourism', as this activity can be moderated in the touristic 'farm', 'play barn' and 'workshop space'. A second example concerns the suggested 'allotment gardens', indicating a synergy between 'agriculture' and 'tourism', as the fruits and vegetables of these gardens (i.e. 'local products') can be sold as 'food packages' in the touristic 'market hall', can be used in the touristic 'restaurant' and can be consumed by means of 'picnic baskets' in the touristic 'picnic areas'. A third example concerns the existing 'educational projects' in the prisons of 'Wortel' (i.e. a bicycle atelier) and 'Merksplas' (i.e. a furniture atelier), indicating a synergy between 'education' and 'tourism'. This means, that once the bicycles have been repaired in the existing 'bicycle atelier', these bicycles can be sold at the touristic 'bicycle service', and that once the furniture has been 'designed' in the existing 'furniture atelier', this furniture can be exhibited in the touristic 'exhibition space'. In this way, we 'prove' that prisoners as socially deprived or vulnerable citizens can be involved, without being physically present at this IEP Site. After all, it was the prisoners' physical presence at this IEP Site, that made them an 'unwelcomed' target group for some partners involved, out of fear that they scare of tourists as visitors. In other words, organigrams can be used as an inspiration for the designer, in order to make an integrated design, by considering in which ways different activities and different citizens can be combined. So in conclusion, we have dealt with this third and 'strategic ambition framework' by means of a mind-opening solution for the redesign. 


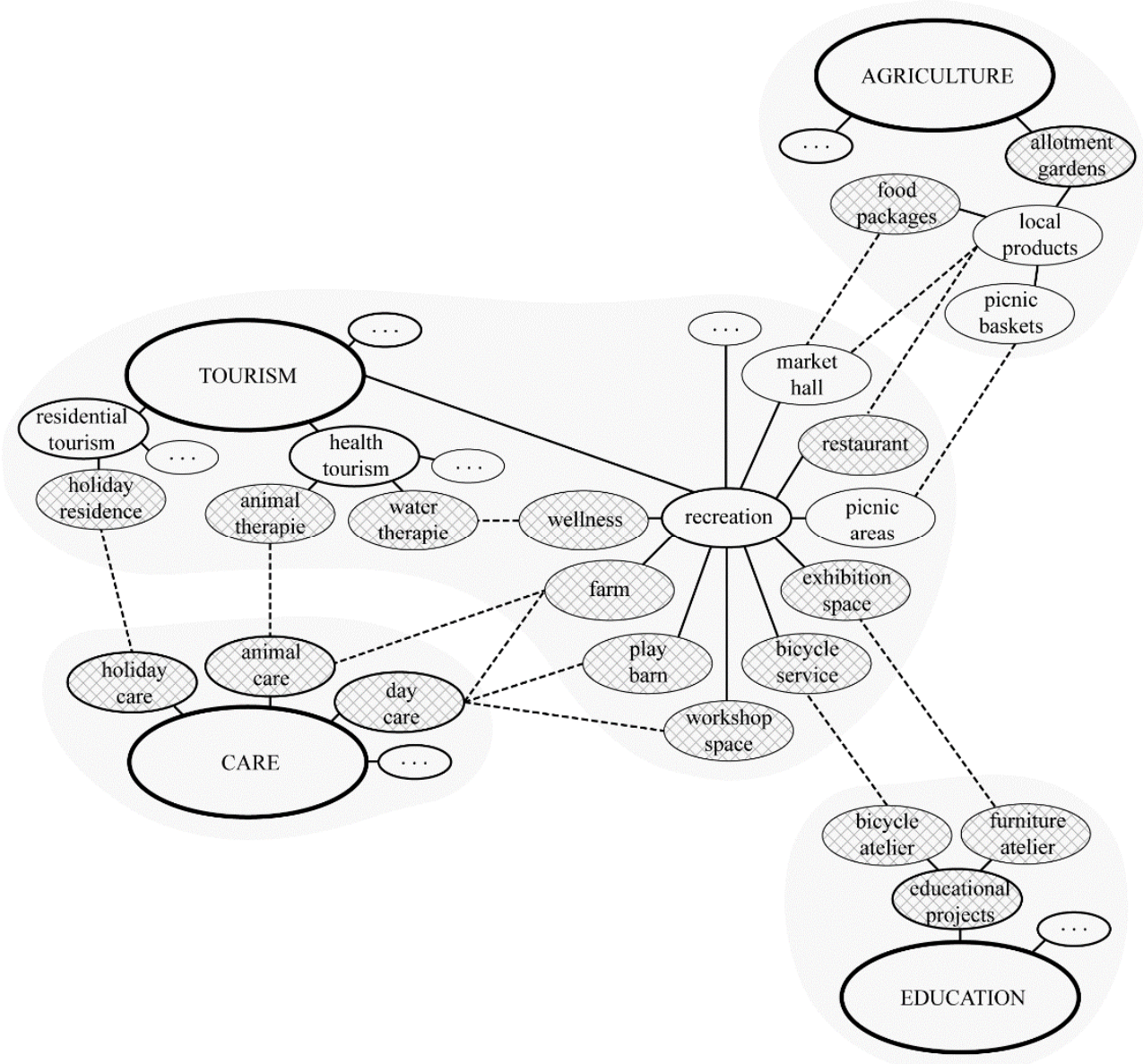

Figure 4: One particular organigram, showing synergies between tourism activities and other activities with a focus on care, education and agriculture (see dotted lines), and marking all so-called 'socio-economic activities' (see hatched surfaces).

\section{CONCLUSIONS}

Like a lot of historical heritage sites all over the world, the Agriculture Pauper Colonies of 'Wortel' and 'Merksplas' have lost their initial function. As a result, a new function has to be found for each one of their historical heritage buildings and spaces. In view of a perfect and desirable 'match', the respective buildings and spaces have to be redesigned and adapted. This kind of process is called 'adaptive reuse'. According to the local governments involved, this new function will consist off the installation off an Inclusive Economic Participation (IEP) Site.

During the process of adaptive reuse, different contextual frameworks need to be taken into account. At first sight, these contextual frameworks seem to work quite 'restrictive' for the redesign. As a result, adaptive reuse is considered not only more difficult for the designer, but also less attractive for developers. However, these contextual frameworks can also work 
quite 'challenging', as we found out during the process of adaptive reuse of both colonies into an IEP Site.

During the process of adaptive reuse, we had to deal with different contextual framework. In particular, it concerned the presence of the 'heritage framework', 'institutional framework' and 'strategic ambition framework'. By means of creative, flexible, innovative and mind-opening solutions for the redesign, the local governments involved could be convinced that the redesign of historical heritage sites does not have to be an obstacle.

\section{REFERENCES}

[1] De Borgher, M., De voormalige Rijksweldadigheidskolonies van Wortel en Merksplas. Monumenten en Landschappen, 18(5), pp. 33-62, 1999.

[2] De Sadeleer S. \& Plomteux, G., Inventaris van het cultuurbezit in België, Architectuur, Provincie Antwerpen, Arrondissement Turnhout, Kanton Hoogstraten. Bouwen door de eeuwen heen in Vlaanderen, 16(4), 2002.

[3] UNESCO, http://whc.unesco.org/en/tentativelists/5841

[4] Latham, D., Creative Reuse of Buildings, Donhead Publishing: Shaftesbury, 2000.

[5] Wilkinson, S., Reed, R. \& Kimberley, J., Using building adaptive reuse to deliver sustainability in Australia. Structural Survey, 27(1), pp. 46-61, 2009.

[6] Bullen, P.A. \& Love, P.E.D., The rhetoric of adaptive reuse or reality of demolition: views from the field. Cities, 27(4), pp. 215-224, 2010.

[7] Bullen, P.A. \& Love, P.E.D., A new future for the past: a model for adaptive reuse decision-making. Built Environment Project and Asset Management, 1(1), pp. 32-44, 2011.

[8] Bullen, P.A. \& Love, P.E.D., Adaptive reuse of heritage buildings. Structural Survey, 29(5), pp. 411-421, 2011.

[9] Plevoets, B. \& Van Cleempoel, P., Adaptive Reuse as a strategy towards conservation of cultural heritage: A literature review. WIT Transactions on The Built Environment, 118, pp. 155-164, 2011.

[10] Termote, H., Arbeid, een kwetsbaar sociaal goed in strijd tegen armoede. Over.Werk, 4, pp. 163-180, 2006.

[11] Vranken, J., Inleiding. Armoede en Sociale Uitsluiting: Jaarboek, eds D. Dierckx et. al., Acco: Leuven, 2010.

[12] Coene J., Dierckx D., Vrancken J. \& Van Haarlem, A., De relatie tussen armoede en arbeid. Over.Werk, 21(2), pp. 86-90, 2011.

[13] Termote, H. \& Galand, S., Deeltijds leren werken: een opstap naar de arbeidsmarkt voor maatschappelijk kwetsbare jongeren? Over.Werk, 3, pp. 52-60, 2012.

[14] De Nys-Ketels, S., Vallet, N. \& Bylemans, M., IEP-sites: ruimtelijke uitdagingen voor een Inclusieve Economische Participatie. Ruimte, 7(28), pp. 66-69, 2015.

[15] Vallet, N., De Nys-Ketels, S. \& Bylemans, M., IEP-sites: een nieuwe kijk op Inclusieve Economische Participatie. Lokaal, 5, pp. 60-61, 2015.

[16] Vallet, N., Bylemans, M. \& De Nys-Ketels, S., Economische participatie van kwetsbare burgers. Sociaal.Net., 2016. http://sociaal.net/opinie/economischeparticipatie-kwetsbare-burgers/

[17] Vallet, N., Bylemans, M. \& De Nys-Ketels, S., Social Economy Sites Aiming for a (More) Inclusive Economic Participation Within an Urbanized Environment, Peter Lang Publishers: Oxford, in press.

[18] Vallet, N., Bylemans, M. \& De Nys-Ketels, S., The Complex Challenge of Inclusive Economic Participation, Exploring the Design of IEP-sites in Flanders. Conference 
Working Paper Series edited by the International Society for the Third Sector (ISTR), in press.

[19] Lucas, K., Transport and social exclusion: Where are we now? Transport Policy, 20, pp. 107-115, 2012.

[20] Opdebeeck, S., Van Audenhove, C. \& Lommertyn, F., De toegankelijkheid van de voorzieningen in de welzijns- en gezondheidszorg. Visies uit de praktijk, het onderzoek ehet beleid, KU Leuven: Leuven, 1998.

[21] Laenen, J., Het Sociaal Huis: een nieuwe structuur? Het Sociaal Huis: huis van de toekomst in welzijnsland?, Map ACW-studiedag i.s.m. het Vlaams centrum voor werknemersvorming (ed.), Elewijt Center: Elewijt, 2001.

[22] Sannen, L., Drempels naar welzijnsvoorzieningen: de cliënt aan het woord, KU Leuven: Leuven, 2002.

[23] Sannen, L., Naar een toegankelijk Sociaal Huis, KU Leuven: Leuven, 2003.

[24] Steenssens, K., Degavre, F., Sannen, L., Demeyer, B. \& Van Regenmortel, T., Leven (z)onder leefloon: Deel 1. Onderbescherming onderzocht, KU Leuven: Leuven, 2007.

[25] De Corte, J. \& Kolijn, S., Eerstelijnszorg via samenwerking tussen lokale besturen en private welzijnsvoorzieningen: de case van het Sociaal Huis in Vlaanderen, UGent: Gent, 2012.

[26] Bylemans, M., Vallet, N. \& Van Acker, M., IEP sites: combining planning tools to address planning uncertainty. Architectural Research Addressing Societal Challenges: Proceedings of the EAAE ARCC $10^{\text {th }}$ International Conference, Lisbon, Portugal, 2016. 